\title{
Antioxidant activity of ultrasonic extracts of leek Allium porrum L.
}

\author{
Jelena D. Mladenović1 ${ }^{1}$ Pavle Z. Mašković ${ }^{1}$, Radoš M. Pavlović ${ }^{1}$, Blaga C. Radovanović2 \\ Gordana Aćamović-Đoković ${ }^{1}$, Milica S. Cvijović ${ }^{1}$ \\ ${ }^{1}$ Faculty of Agronomy, University of Kragujevac, Čačak, Serbia \\ ${ }^{2}$ Faculty of Science, University of Niš, Niš, Serbia
}

\begin{abstract}
This study was aimed at evaluating the antioxidant activity and efficacy of the ethanolic extract of the ultrasonic extracts of leek Allium porrum L. Ethanolic (50 vol.\%) extracts of edible leek parts (stem and leaf) were prepared by ultrasound-assisted extraction, which was followed by evaluation of total phenols, flavonoids and antioxidant activity. Total phenols were determined using the modified Folin-Ciocalteu method. Antioxidant activity was assessed by scavenging the stable free radical 2,2-diphenyl-1-picrylhydrazyl (DPPH). The results of antioxidant activity were compared with control antioxidants: vitamin C and BHT. The higher content of phenols ( $69.46 \mathrm{mg} \mathrm{GAE} / \mathrm{g}$ dry extract) and flavonoids ( $33.53 \mathrm{mg} \mathrm{CE} / \mathrm{g}$ dry extract) was found in the ethanolic extract of leek stem. The measured values of $I C_{50}$ were 98.90 and $61.05 \mu \mathrm{g} / \mathrm{mL}$ for the ethanolic extract of leek leaf and stem, respectively.
\end{abstract}

\section{SCIENTIFIC PAPER}

UDC 66.061.3:635.261:54.018

Hem. Ind. 65 (4) 473-477 (2011)

doi: 10.2298/HEMIND110301033M

Keywords: ultrasonic extracts; leek; stem; leaf; antioxidant.

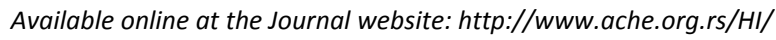

Phenolic compounds exhibiting antioxidant properties are an important component contributing to the beneficial effect of fruits and vegetables on human health [1]. Their ability to affect diseases resulting from oxidative stress has not been sufficiently elucidated. Flavonoids include a large number of compounds present in plants that have been used in both traditional and Eastern medicine for more than a thousand years. Pharmacologically speaking, these compounds show a broad spectrum of biochemical and pharmacological activities [2]. Different flavonoids have diverse antioxidant, antibacterial, anti-inflammatory, antiallergic, antimutagenic, antiviral, antithrombotic and vasodilative actions, with antioxidant and anti-inflammatory effects being the most pronounced [3]. These compounds are active in chronic inflammatory and allergic diseases, breast cancer and cardiovascular diseases [4]. Particular attention has been focused on their capacity to protect against and prevent cardiovascular diseases, in light of the fact that epidemiological studies have shown that flavonoids provide protection against the development of these diseases.

Most natural antioxidants are phenolic compounds [5]. In food, cosmetic and pharmaceutical industries, the most commonly used antioxidants include synthetic ones such as BHA (a mixture of 2-tert-butyl-4-hydroxyanisole and 3-tert-butyl-4-hydroxyanisole isomers) and BHT (2,6-di-tert-butyl-4-metylphenol). The use of syn-

Correspondence: J. Mladenović, Department of Chemistry and Chemical Engineering, Faculty of Agronomy, University of Kragujevac, Cara Dušana 34, 32000 Čačak, Serbia.

E-mail: jelenaml@tfc.kg.ac.rs

Paper received: 1 March, 2011

Paper accepted: 12 May, 2011 thetic antioxidants is prohibited in some countries due to their long-term undesirable toxicological effects, including mutagenic, carcinogenic and teratogenic ones [6]. Moreover, the use of synthetic antioxidants is limited due to increasing consumer demand for additive-free food. Therefore, numerous studies conducted over the last few decades have been focused on identifying new antioxidants from natural sources. A major tendency in the food industry today is to obtain natural antioxidants from the plant material [7]. Extracts from the plant biomass are an important source of nutritional supplements, functional food components or antioxidants in the food industry. The tendency to replace synthetic compounds by active natural components has aimed research towards studies on different plant materials and identification of new extractable compounds having antioxidant effects. Huge efforts have therefore been made towards both the identification of cheap sources of natural antioxidants and the development of effective selective extraction techniques.

\section{EXPERIMENTAL}

\section{Plant material}

The Dutch leek (Allium porum L.) cultivar Varna characterized by medium early maturation, long white stem of uniform length and short green leaves that can be preserved for a long period of time was used as the plant material in this study. The plant was cultivated under open field conditions during the autumn growing cycle in 2010 on an experimental field at Trbušani, near Čačak. During the stage of leek harvest maturity, samples of edible parts, i.e., stem and leaf were collected for extraction, and cut longitudinally into thin strips. 


\section{Chemicals}

All chemicals and reagents were of analytical grade and were purchased from Sigma Chemical Co. (St Louis, $\mathrm{MQ}$, USA), Aldrich Chemical Co. (Steinheim, Germany) and Alfa Aesar (Karlsruhe, Germany).

\section{Spectrophotometric measurements}

Spectrophotometric measurements were performed using an MA9523-SPEKOL 211 UV-Vis spectrophotometer (ISKRA, Horjul, Slovenia).

\section{Preparation of extracts}

Extract preparation involves the extraction of phenolic substances by ultrasound-assisted extraction. UItrasound-assisted extraction used for process intensification purposes is commonly referred to as sonification, involving the use of high-frequency ultrasound in the extraction of substances from plant materials. UItrasound induces cell destruction, cell size reduction and propagation of ultrasonic waves through solid material, leading to a larger solid-liquid interface and better contact of the solvent with the components [8]. The extracts were obtained by ultrasound-assisted extraction using a Brason B-220 ultrasonic bath (Smith-Kline Company, USA). The typical procedure involved ultrasound-assisted extraction of crushed plant material with $95 \%$ ethanol over a period of $1 \mathrm{~h}$.

\section{Determination of total phenolic}

Total phenols were estimated according to the Folin-Ciocalteu method [9]. Plant extracts were diluted to a concentration of $1 \mathrm{mg} / \mathrm{mL}$, and aliquots of $0.5 \mathrm{~mL}$ were mixed with $2.5 \mathrm{~mL}$ of Folin-Ciocalteu reagent (previously diluted 10 -fold with distilled water) and 2 $\mathrm{mL}$ of $\mathrm{NaHCO}_{3}(7.5 \%)$. After 15 min of incubation at 45 ${ }^{\circ} \mathrm{C}$ the absorbance was measured at $765 \mathrm{~nm}$ in a spectrophotometer against a blank sample. Total phenols were determined as gallic acid equivalents ( $\mathrm{mg} \mathrm{GA} / \mathrm{g}$ extract), and the values are presented as means of triplicate analyses [10].

The leek extracts obtained were analyzed for total phenols and flavonoids using spectrophotometric methods. Total phenols were determined as gallic acid equivalents (mg GAE/g dry extract), and the values are presented as means of triplicate analyses.

\section{Determination of flavonoid content}

The total flavonoid content was determined according to Takao et al. [11]. A total of $0.5 \mathrm{~mL}$ of $2 \%$ aluminium chloride $\left(\mathrm{AlCl}_{3}\right)$ in methanol was mixed with the same volume of methanol solution of plant extracts [12]. After 1 hour-incubation at room temperature, the absorbances of the samples were measured at $415 \mathrm{~nm}$ in a spectrophotometer against a blank sample. Total flavonoids were determined as (+)-catechin equivalents (mg CE/g dry extract), and the values are presented as means of triplicate analyses.

\section{Determination of total antioxidant capacity}

The total antioxidant activity of the ethanolic extracts tested was evaluated by the phosphomolybdenum method [13]. The assay is based on the reduction of Mo (VI)/Mo (V) by antioxidant compounds and subsequent formation of a green phosphate/Mo (V) complex at acid $\mathrm{pH}$. A total of $0.3 \mathrm{~mL}$ of sample extracts was combined with $3 \mathrm{~mL}$ of reagent solution (0.6 M sulfuric acid, $28 \mathrm{mM}$ sodium phosphate and 4 $\mathrm{mM}$ ammonium molybdate). The tubes containing the reaction solution were incubated at $95{ }^{\circ} \mathrm{C}$ for $90 \mathrm{~min}$ [14]. Then the absorbance of the solution was measured at $695 \mathrm{~nm}$ using a spectrophotometer against a blank after cooling to room temperature. Ethanol (0.3 $\mathrm{mL}$ ) in the place of extract was used as the blank. Ascorbic acid (AA) was used as standard and the total antioxidant capacity was expressed as $\mathrm{mg}$ of ascorbic acid per $g$ of the dry extract.

\section{Determination of DPPH free radical scavenging activity}

The method used by Kumarasamy et al. [15] was adopted with suitable modifications from Prieto et al. [16]. DPPH (8 mg) was dissolved in $\mathrm{MeOH}(100 \mathrm{~mL})$ to obtain a concentration of $80 \mu \mathrm{g} / \mathrm{mL}$. Serial dilutions were carried out with the stock solutions $(1 \mathrm{mg} / \mathrm{mL})$ of the extracts. The solutions $(2 \mathrm{~mL}$ each) were then mixed with DPPH $(2 \mathrm{~mL})$ and allowed to stand for 30 min for any reaction to occur, and the absorbance was measured at $517 \mathrm{~nm}$. Ascorbic acid (AA), gallic acid (GA) and butylated hydroxytoluene (BHT) were used as reference standards and dissolved in methanol to make the stock solution with the same concentration $(1 \mathrm{mg} /$ $/ \mathrm{mL})$, [17]. The control sample was prepared containing the same volume without test compounds or reference antioxidants. Ninety-five percent methanol was used as blank. The DPPH free radical scavenging activity (\%) was calculated using the following equation:

$\%$ Inhibition $=\frac{A c-A s}{A c} \times 100$

where $A c$ is DPPH of the stock solution + methanol, As - DPPH of the stock solution + sample (or standard solution).

The $I C_{50}$ value, defined as the concentration of the test material leading to a $50 \%$ reduction in the free radical concentration, was calculated as $\mu \mathrm{g} / \mathrm{mL}$ through a sigmoidal dose-response curve.

\section{Statistical analysis}

All the results are presented as mean \pm standard deviations of three determinations. All computations we- 
re made by employing the statistical software (SPSS, version 11.0$)$. $I C_{50}$ values were calculated using Origin Pro 8 statistical software from the sigmoidal inhibition curve.

\section{RESULTS AND DISCUSSION}

\section{Total phenolic content (TPC)}

The results on the determination of the total phenolic content in the plant extracts using the Folin-Ciocalteu method are given in Table 1 . The content of total phenols in the extracts, expressed as gallic acid equivalents (GAE), were 45.39 and $69.46 \mathrm{mg} / \mathrm{g}$ dry for leaf and stem extract, respectively.

\section{Flavonoid content}

The results on the determination of flavonoid contents (expressed as catechin equivalents: $\mathrm{mgCE} / \mathrm{g}$ of dry extract) are given in Table 1.

\section{Total antioxidant activity}

The phosphomolybdenum method, an assay based on the reduction of $\mathrm{Mo}(\mathrm{VI}) / \mathrm{Mo}(\mathrm{V})$ by the antioxidant compounds and subsequent formation of a green phosphate/Mo(V), is quantitative since the antioxidant activity is expressed as the number of equivalents of ascorbic acid (AA) per g of dry extract. The results for total antioxidant capacity are given in Table 1 . Higher total antioxidant capacity showed the ethanol extract of leaf leek.

\section{DPPH free radical scavenging activity}

Substances which are able to donate hydrogen or an electron to $\mathrm{DPPH}^{\circ}$, a nitrogen-centered free radical, can be considered as antioxidants and therefore radical scavengers. The degree of discoloration of the violet color of $\mathrm{DPPH}^{\bullet}$, as it gets reduced, indicates the radical-scavenging potential of the antioxidant [18]. Results of the $\mathrm{DPPH}^{\circ}$ scavenging activity are given in Figure 1. Ethanol extract steam $I C_{50}=61.05 \mu \mathrm{g} / \mathrm{mL}$ showed better antioxidant activity of ethanol extract of leaf 98.9 $\mu \mathrm{g} / \mathrm{mL}$, they were less effective than $\mathrm{AA} / C_{50}=10.61$ $\mu \mathrm{g} / \mathrm{mL}$ and $\mathrm{BHT}=39.25 \mu \mathrm{g} / \mathrm{mL}$.

\section{Correlation between total phenolic/flavonoid content and antioxidant activity}

Antioxidant activities of polyphenols are mainly due to their ability to act as hydrogen donors, reducing agents and radical scavengers [19]. The leek ethanolic extract of stem which had higher phenolic and flavonoid content showed higher antioxidant activity in terms of DPPH radical scavenging activity, but lower total antioxidant capacity. In previous phytochemical studies on the ethanolic extract of leek, gallic acid, a well known strong natural antioxidant [20], and its derivatives methyl gallate and pentagalloyl glucose were isolated [21].

Table 1. Total phenolic and flavonoid contents and total antioxidant capacityof a leek; extractant: ethanol

\begin{tabular}{lccc}
\hline Plant part used & $\begin{array}{c}\text { Total phenolic content } \\
\text { mgGAE/g dry extract }\end{array}$ & $\begin{array}{c}\text { Flavonoid content } \\
\text { mgCE/g dry extract }\end{array}$ & $\begin{array}{c}\text { Total antioxidant capacity } \\
\text { mgAA/g dry extract }\end{array}$ \\
\hline Leaf & $45.39 \pm 2.52$ & $10.24 \pm 2.84$ & $131.37 \pm 3.18$ \\
Stem & $69.46 \pm 1.65$ & $33.53 \pm 2.51$ & $123.80 \pm 8.03$ \\
\hline
\end{tabular}

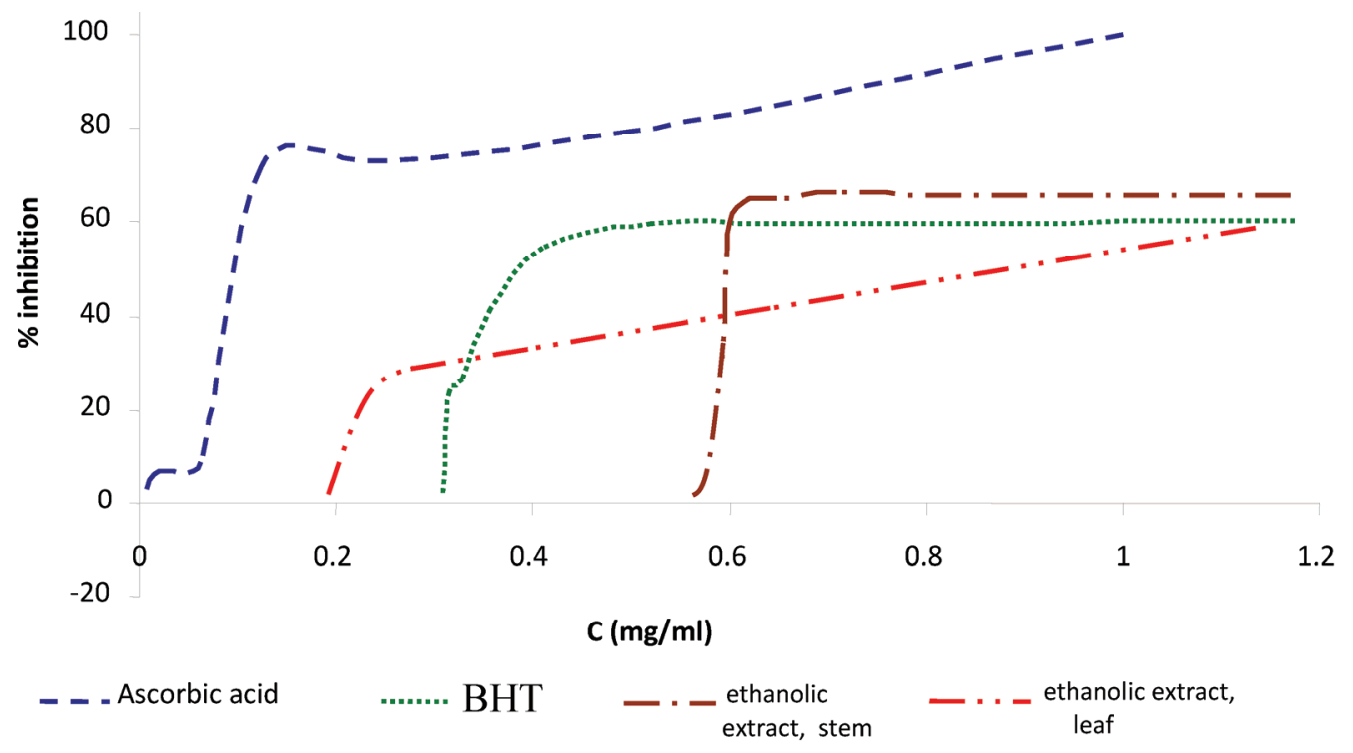

Figure 1. DPPH free radical scavenging activity. Each value is expressed as meantstandard deviation. 


\section{CONCLUSION}

Ultrasonic extracts of leek parts can be used in the food industry not only for product protection against oxidation but also due to their numerous biological and pharmacological activities. The above can be of high practical importance.

\section{Acknowledgments}

This study is part of the TR 31059 project entitled "A New Concept in Breeding Vegetable Cultivars and Hybrids Designed for Sustainable Growing Systems Using Biotechnological Methods", financially supported by the Ministry of Science and Technological Development, Republic of Serbia.

\section{REFERENCES}

[1] M.S. Anthony, T.B. Clarkson, B.C. Bullock, J.D. Wagner, Soy protein versus soy phytoestrogens in the prevention of diet-induced coronary artery atherosclerosis of male cynomolgus monkeys, Arterioscler. Thromb. Vasc. Biol. 17 (1997) 2524-2531.

[2] I.M.C. Brighente, M. Dias, L.G Verdi, M.G Pizzolatti, Antioxidant activity and total phenolic content of some Brazilian species. Pharm. Biol. 45 (2007) 156-161.

[3] H.W Felter, The Eclectic Materia Medica, Pharmacology and Therapeutics, 1922.

[4] B.V Howard, D.Kritchevsky, Phytochemicals and cardiovascular disease: a statement for healthcare professsionals from the American Heart Association, Circulation 95 (1997) 2591-2593.

[5] A. Basile, S. Sorbo, S. Giordano, L. Ricciardi, S. Ferrara, D. Montesano, M.N.Clifford, Chlorogenic acids and other cinnamates-nature, occurrence and dietary burden, J. Sci. Food. Agric. 79 (1999) 362-372.

[6] A. Cassidy, B. Hansley, R.M. Lamuela-Raventos, Isoflavones, lignans and stilbenes-origins, metabolism and potential importance to human health, J. Sci. Food. Agric. 80 ( 2000) 1044-1062.

[7] J. Onyilagha,, E. Grotewold, The biology and structural distribution of surface flavonoids, Recent Res. Devel. Plant Sci. 2 (2004) 53-71.

[8] M. Vinatoru, M. Toma, O. Radu, P.I. Filip, D. Lazurca, T.J. Mason, The use of ultrasound for the extraction of bio- active principles from plant materials, Ultrason. Sonochem. 4 (1997) 135-139.

[9] S.M.K. Rates, Plants as source of drugs, Toxicon 39 (2001) 603-613.

[10] I.C.W Arts, B. Van de Putte, P.C.H. Hollman, Catechin contents of foods commonly consumed in The Netherlands, Fruits, vegetables, staple foods, and processed foods, J. Agric. Food. Chem. 48 ( 2000 ) 1746-1751.

[11] T. Takao, N. Watanabe, I. Yagi, K.A. Sakata, Simple screening method for antioxidants and isolation of several antioxidants produced by marine bacteria from fish and shellfish, Biosci. Biotechnol. Biochem. 58 (1994) 1780-1783.

[12] Q.Y. Zhu, A.O.Zhang, D.Tsang, Y. Huang, Z.Y. Chen, Stability of green tea catechins, J. Agric. Food. Chem. 45 (1997) 4624-4628.

[13] Ph. JUG. IV, Pharmacopoeia Jugoslavica, $4^{\text {th }}$ ed., National Institute for Health Protection: Belgrade, 1984.

[14] F. Tomas-Barberan, M. Clifford, Flavanones, chalcones and dihydrochalconesnature, occurrence and dietary burden, J. Sci. Food. Agric. 80 (2000)1073-1080.

[15] Y. Kumarasamy, M. Byres, P.J. Cox, M. Jaspars, L. Nahar, S.D. Sarker, Screening seeds of some Scottish plants for free-radical scavenging activity, Phytother. Res. 21 (2007) 615-621.

[16] P. Prieto, M. Pineda, M. Aguilar, Spectrophotometric quantitation of antioxidant capacity through the formation of a phosphomolybdenum complex: specific application to the determination of vitamin E, Anal. Biochem. 269 (1999) 337-341.

[17] F. Shahidi, M. Naczk, Food Phenolics, Sources, Chemistry, Effects, Applications, PA, Technomic Publishing Co. Inc., Lancaster, 1995.

[18] F. Sosulski, K.Krygier, L.Hogge, Free, esterified, and insoluble-bound phenolic acids, composition of phenolic acids in cereal and potato flours, J. Agric. Food. Chem. 30 (1982) 337-340.

[19] A.R. Ness, J.W. Powles, Fruit and vegetables and cardiovascular disease: a review, Int. J. Epidemiol. 26 (1997) 1-13.

[20] J.B. Harborne, C.A. Williams, Advances in flavonoid research since 1992, Phytochemistry 55 ( 2000) 481-504.

[21] C. Lakenbrink, S. Lapczynski, B. Maiwald, U.H. Engelhardt, Flavonoids and other polyphenols in consumer brews of tea and other caffeinated beverages, J. Agric. Food. Chem. 48 (1996) 2848-2852. 


\section{IZVOD}

\section{ANTIOKSIDATIVNA AKTIVNOST ULTRAZVUČNIH EKSTRAKATA PRAZILUKA Allium porrum L.}

Jelena D. Mladenović ${ }^{1}$, Pavle Z. Mašković ${ }^{1}$, Radoš M. Pavlović ${ }^{1}$, Blaga C.Radovanović ${ }^{2}$, Gordana Aćamović-Đoković ${ }^{1}$, Milica S. Cvijović ${ }^{1}$

${ }^{1}$ Agronomski fakultet, Univerzitet u Kagujevcu, Čačak, Srbija

${ }^{2}$ Prirodno-matematički fakultet, Univerzitea u Nišu, Niš, Srbija

(Naučni rad)

Rad je koncipiran sa ciljem da se ispita antioksidativna aktivnost etanolskog ekstrakta napravljenog ultrazvučnom ekstrakcijom vrste praziluka, Allium porrum L. U ovim ispitivanjima pripremljeni su etanolni (50 vol.\%) ekstrakti jestivih delova praziluka odnosno stabla i lista postupkom ultrazvučne ekstrakcije, a potom je određen sadržaj ukupnih fenola, flavonoida i antioksidativna aktivnost. Ukupni fenoli su određeni metodom po Folin-Ciocalteu, dok je antioksidativno delovanje određeno DPPH „scavenging” metodom. Dobijeni rezultati za antioksidativnu aktivnost su upoređeni sa kontrolnim antioksidantima: vitaminom C i BHT. Veća količina fenola $(69,46 \mathrm{mg} \mathrm{GAE} / \mathrm{g}$ suvog ekstrakta) i flavonoida (33,53 mg CE/g suvog ekstrakta) nađena je $u$ etanolnom ekstraktu stabla praziluka. Vrednosti $C_{50}$ iznosile su $98,90 \mu \mathrm{g} / \mathrm{ml}$ za etanolski ekstrakt lista i $61,05 \mu \mathrm{g} / \mathrm{ml}$ za etanolni ekstrakt stabla praziluka.

Ključne reči: Ultrazvučna ekstrakcija Praziluk • Stablo • List • Antioksidans 